\title{
Socio-economic status as an indicator of farmers family well being
}

\author{
SUMAN SINGH, HEMU RATHORE AND CHARU SHARMA
}

Received: 24.05.2017; Revised: 13.10.2017; Accepted: 27.10.2017

See end of the paper for authors' affiliations HEMU RATHORE

Department of Family Resource

Management, College of Home Science,

Maharana Pratap University of

Agriculture and Technology, UDAIPUR (RAJASTHAN) INDIA

Email : rathorehemu@ rediffmail. com
ABSTRACT : Women in India are the backbone of the society and important human resource. Women constitute nearly half the population in any country either it is developed or developing country. They play a significant and crucial role in agriculture and allied operations and household activities. Without socio-economic equality for women in poor sectors of India, the impacts of efforts at development can not become fully realized. Socio-economic status (SES) is an important determinant of the health, nutritional status, mortality, and morbidity of an individual. Through this paper an attempt has been made to assess socio-economic status of farm families of selected villages of Relmagra block of Rajsamand district. The data revealed that a vast majority of household had low socio-economic status in spite of good land holding and irrigation facilities, this calls for bringing improvement in land utilization pattern and diversifying the cultivation pattern.

KEY WORDS: Socio-economic status, Agriculture, Farm families, Development

- HOW TO CITE THIS PAPER : Singh, Suman, Rathore, Hemu and Sharma, Charu (2017). Socioeconomic status as an indicator of farmers family well being. Asian J. Home Sci., 12 (2) : 482-488, DOI: 10.15740/HAS/AJHS/12.2/482-488. 